\title{
NATIONAL IRISH BANK v RTE AND FINDING THE BALANCE: BREACH OF CONFIDENCE, PRIVACY AND THE PUBLIC INTEREST TEST IN ENGLAND AND IRELAND
}

\author{
Helen Fenwick, Professor of Law and Gavin Phillipson, Lecturer in \\ Law, Human Rights Centre, University of Durham. ${ }^{1}$
}

\section{INTRODUCTION}

It is now well known that the primary vehicle since the Human Rights Act 1998 for providing greater protection in England against invasion of the privacy by the media has been breach of confidence. ${ }^{2}$ The doctrine of confidence, which had been used for some time in English law to deal with situations concerning the unauthorised use of commercial information, state secrets $^{3}$ and personal data, ${ }^{4}$ is now becoming, under the impetus of the Human Rights Act (hereafter HRA), something close to a fully-fledged privacy law. No such development is apparent so far in Ireland. However, the introduction into Irish law of Article 8 (the right to respect for private life) of the European Convention on Human Rights via the European Convention on Human Rights Act 2003 (hereafter ECHRA) may also provide the impetus, as in England, for the development of breach of confidence into a de facto privacy remedy.

It is possible that the right to privacy, as one of the un-enumerated rights under Article 40.3.1 of the Irish Constitution, might be relied upon instead, rendering such a development unnecessary. ${ }^{5}$ This might have been expected to be the case already, bearing in mind its direct horizontal effect. However, this is not a development that has occurred so far (although Article 8 under

1 A draft of this paper was originally delivered at a Symposium on Freedom of Expression, 5-6 December 2003, held at Trinity College, Dublin.

2 See Venables and another v News Group Newspapers [2001] 1 All ER 908; Douglas and Zeta-Jones v Hello! [2001] QB 967, at 997 (CA) (application for interim injunction to restrain surreptitiously taken photographs of a celebrity wedding); Douglas and Zeta-Jones v Hello! [2003] EWHC 786 (Ch) (final trial, hereafter, "Douglas II)"; A v B plc [2002] 3 WLR 542 (CA) (concerned with whether an injunction should be granted to restrain publication of details of premiership footballer's affair with a lap-dancer); Campbell v MGN [2003] 2 WLR 80 (CA) (action to restrain publication of details of the model's treatment at Narcotics Anonymous, including photographs of her outside the clinic); Theakston v MGN [2002] EMLR 22 (application to restrain detailed description and photographs of the TV presenter's visit to a brothel given to the Sunday People by a prostitute); Mills v News Groups Newspapers (injunction preventing publication of the applicant's address in The Sun refused); see $e g$ R. Singh and T. Strachan, "The Right to Privacy in English Law" [2002] EHRLR 129; G. Phillipson, "Transforming Breach of Confidence? Towards a common law right of privacy under the Human Rights Act" [2003] 66(5) MLR 726.

3 A-G v Guardian Newspapers [1987] 3 All ER 316.

4 Stephens v Avery [1988] Ch 449; 2 All ER 477; 2 WLR 1280.

5 See $M$ v Drury [1994] 2 IR 8. 
the ECHRA might provide the guidelines for such a development) and therefore courts and potential litigants may prefer to rely on the doctrine of confidence, interpreted in line with Article 8 ECHR and the established English post-HRA case-law discussed in this article on confidence as a privacy remedy. In support of this point it may be noted that in McDonnell $\mathrm{v}$ Ireland ${ }^{6}$ Barrington J said: "If the general law provides an adequate cause of action to vindicate a constitutional right it appears to me that the injured party cannot ask the court to devise a new and different cause of action." Arguably, the doctrine of confidence - if developed along the lines argued for in this article - already provides the means of vindicating the implied right of privacy under the Constitution at least in cases of unauthorised publication of personal information. In that context, the development of the public interest defence to the breach of confidence action in Irish law, as illustrated by the decision of the Supreme Court in National Irish Bank v RTE (hereafter $N I B \vee R T E$ ), is particularly significant. This decision has received remarkably little academic attention and is surely now due for re-evaluation, given the further developments that may be expected in the public interest defence following the introduction of Article 10 of the Convention (the right to freedom of expression) into Irish law. ${ }^{8}$ This paper is concerned primarily with the extent to which the Irish doctrine of confidence is ripe for development into a privacy law, and, in particular, the implications for the public interest defence of such a development.

It is necessary to begin, therefore, by examining the elements of breach of confidence, as interpreted by the Irish courts, in particular in the NIB $\mathrm{V} R T E$ case, and to compare the Irish approach with the more flexible one adopted by English courts, both before and after the HRA.

\section{THE ELEMENTS OF BREACH OF CONFIDENCE}

\section{The Development Of The English Doctrine}

The House of Lords in Attorney General v Guardian Newspapers (No 2) ${ }^{9}$ found that the ruling in Coco v AN Clark (Engineers) Limited ${ }^{10}$ conveniently summarised the three traditionally accepted key elements of the law of confidence:

"First the information itself . . . must have the necessary quality of confidence about it. Secondly, that information must have been imparted in circumstances importing an obligation of confidence. Thirdly, there must be an unauthorised use of

\footnotetext{
6 [1998] 1 IR 141.

[1998] 2 IR 465.

8 See $\mathrm{n} 68$ below for one of the few commentaries on NIB $\mathrm{v}$ RTE. The Irish Constitution, both explicitly in Art 40.6.1 and as one of the un-enumerated rights in Art 40.3.1, provides for a right to freedom of expression. In this paper, however, we concentrate upon the possible impact of Art 10 ECHR; O'Dell comments that Art 40.6.1 "has failed to develop any meaningful protection for speech" (Eoin O'Dell, "When two tribes go to war: Privacy Interests and Free Speech" in Law and the Media: Views of Journalists and Lawyers (Dublin: Sweet and Maxwell, 1997), at 241).

9 [1990] 1 AC 109.

10 [1969] RPC 41, at 47.
} 


$$
\begin{aligned}
& \text { that information to the detriment of the party communicating } \\
& \text { it." }
\end{aligned}
$$

For our purposes it is the second element that is of greatest interest, since it is in that element that the most radical developments have occurred in the English courts. Traditionally, this requirement founded liability on the basis that if information was accepted on the understanding that it would be kept secret, the recipient's conscience would be bound by that undertaking, and it would be unconscionable for him to break his duty of confidence by publishing the information to others. ${ }^{11}$ It is accepted in both English and Irish courts that this second element will be present in the following situations: first, where a pre-existing relationship of trust and confidence exists between plaintiff and defendant; ${ }^{12}$ second, where there has been an express agreement of confidentiality between the parties or promise to that effect by the defendant; ${ }^{13}$ and third, where the defendant is a third party to such a relationship but has acquired confidential information communicated between the parties to that relationship. English law has recognised a fourth category of cases: those in which the confidential information in question is surreptitiously taken or acquired by the defendant. Each category successively widens the ambit of the action. The difference between the first three categories and the fourth is that in relation to the first three there must be a relationship of fidelity or express agreement of confidentiality; in the fourth, neither of these elements is needed; the defendant may indeed be a stranger to the plaintiff.

This fourth category does not appear to have been clearly recognised in Ireland although there are many pre-HRA English cases on surreptitious takings of information. As early as 1913, it was said:

"The principle upon which the Court of Chancery has acted for many years has been to restrain the publication of confidential information surreptitiously obtained or of information imparted in confidence which ought not to be divulged."14

There have been numerous cases since illustrating that an obligation of confidence may be imposed in such circumstances, ${ }^{15}$ as well as dicta to this effect at the highest level. ${ }^{16}$ Thus English decisions moved the doctrine to the

11 As stated, for example, in Stephens v Avery [1988] Ch 449.

12 See eg W v Edgell [1990] Ch 59 (doctor-patient); X v Y [1988] 2 All ER 650 and Attorney General v Guardian Newspapers [1987] 1 WLR 1248 (both employeremployee).

13 Law Commission, Breach of Confidence (Law Com No 110), at para 6.11.

14 Ashburton v Pape [1913] 2 Ch 419.

15 See eg Francome v Mirror Group Newspapers [1984] 1 WLR 892 (information obtained through the use of an unlawful telephone tap); Shelley Films v Rex Features Limited [1994] EMLR 134 (injunction granted to prevent the use of a photograph taken surreptitiously on the film set of Frankenstein); Creation Records Ltd v News Groups Newspapers Ltd [1997] EMLR 444 (injunction granted to prevent publication of a photograph of an album cover design taken surreptitiously on the set).

16 Lord Goff suggested in A-G v Guardian Newspapers (No 2) [1990] 1 AC 109, at 281 , that an obligation could be imposed where ". . . an obviously confidential document is wafted by an electric fan out of the window into a crowded street, or 
point at which the obligation of confidence could be imposed unilaterally; it was no longer founded on the express or implied agreement of the parties that the communication would be confidential. This approach had in fact already been indicated in Coco v A $N$ Clark (Engineers) Limited: it was said that the obligation would be imposed if ". . . the circumstances are such that any reasonable man standing in the shoes of the recipient of the information would have realised that upon reasonable grounds the information was given to him in confidence ..." 17 The test appears to be wholly objective - actual appreciation by the defendant that an obligation has been imposed seems to be unnecessary. These developments, as the authors argued before the HRA came into force, ${ }^{18}$ rendered the doctrine useable as "a privacy law in all but name." 19 If all that was necessary to impose an obligation of confidentiality was the application of a reasonable man test, then not only did any need for pre-existing relationships or express agreements of confidentiality fall away: in addition, there needed to be nothing recognisable as a "communication" from the plaintiff to any other person for the duty to arise. Therefore the doctrine offered the potential to be used against journalists seeking to publish material obtained surreptitiously from the defendant through, for example, photography using long-range lenses, or bugging devices, since in such cases it would be possible for the plaintiff to argue that, where the information obtained was clearly private in character, a reasonable man would have understood that s/he was obliged to treat it as confidential. ${ }^{20}$ This, we suggest, could come about entirely as a result of the nature of the information in question, coupled sometimes with the fact that the defendant had to resort to surreptitious means to acquire it. Post-HRA cases have clearly confirmed this development. Thus in $A \mathrm{v} B$ plc the Court of Appeal observed:

"The need for the existence of a confidential relationship should not give rise to problems as to the law . . . A duty of confidence will arise whenever the party subject to the duty is in a situation where he either knows or ought to know that the other person can reasonably expect his privacy to be protected." 21

There are a number of cases under the HRA in which a prima facie obligation has been imposed upon journalists obtaining personal information surreptitiously in this way. ${ }^{22}$ The key point for present purposes is that the

when an obviously confidential document ... is dropped in a public place and is then picked up by a passer-by ..."

$17 \mathrm{n} 10$ above, at 48.

18 See G. Phillipson and H. Fenwick, "Confidence and Privacy: a Re-examination" [1996] 55 CLJ 447; "Breach of Confidence as a Privacy Remedy in the Human Rights Act Era" [2000] 63(5) MLR 660.

19 Ibid $(M L R)$, at 693.

20 Problems remain over the issue of information that is arguably "private" in character but which can only with difficulty be characterized as "confidential," because, for example, it consists of a photograph taken of the plaintiff in a public place such as a park, beach or restaurant. On this, however, see now Peck v UK (2003) 36 EHRR 41 and the analysis thereof in Phillipson, n 2 above, at 738-740.

$21 \mathrm{n} 2$ above, at 551B (emphasis added).

22 These include Theakston (n 2 above) in relation to the photographs surreptitiously taken of Theakston in the brothel; Venables and Thompson (n 2 above) (since the injunctions applied regardless of how the information - as to the identity and 
foundations for this radical development were laid, as noted above, long before the HRA: they relied upon replacing the notion of a relationship or agreement of confidentiality (whether express or implied) as the necessary element in imposing an obligation of confidentiality, with the notion of the imposition of such an obligation through an objective "reasonable man" test. Cases since the HRA have simply structured the "reasonable man" test by reference to the notion of a reasonable expectation of privacy, arising because of the nature of the information and the circumstances in which it was obtained. It is also, of course, the case that developing confidence in this way allows much more comprehensive protection to be given to trade secrets and the like than would have been the case if the restrictive conditions traditionally surrounding the doctrine had continued to be strictly enforced: indeed, one of the main sources of impetus behind the English development of the doctrine was the very injustice that would have arisen if a defendant who surreptitiously and unconscionably obtained clearly confidential information and then used it for his own benefit could have escaped liability for breach of confidence simply because of the absence of a pre-existing relationship with the plaintiff or a promise of confidentiality. As Browne-Wilkinson VC observed in English and American Insurance Co Ltd v Herbert Smith:

"If somebody is handed a letter [addressed] to another marked "Private and Confidential", that letter having been handed to him in error, and he chooses to read it notwithstanding that it is marked "Private and Confidential" and as a result acquires the information contained in the letter, I find it difficult to say that he is not implicated in the leakage of confidential information so contained in the letter." 23

Many of the older general formulations of the doctrine are not in fact prescriptive as to the circumstances needed to impose an obligation of confidentiality. As Lord Greene MR put it in Saltman Engineering Co Ltd v Campbell Engineering Co. Ltd:

"If a defendant is proved to have used confidential information, directly or indirectly obtained from a plaintiff, without the consent, express or implied of the plaintiff, he will be guilty of an infringement of the plaintiff's rights." 24

It may be noted that this formulation simply omits the second limb of breach of confidence set out in Coco Engineering, implying perhaps that, whilst the Coco formulation is generally seen as authoritative, it is not to be compared to a statutory definition: the common law retains its inherent flexibility and formulations such as that in Saltman indicate that the second limb - at least as traditionally understood - is by no means sacrosanct.

whereabouts of the boys - was obtained in principle) and Campbell, (n 2 above) in which it was accepted that an obligation could in principle be imposed in relation to photographs surreptitiously taken of Campbell outside Narcotics Anonymous although the action failed on other grounds. For discussion, see Phillipson, n 2 above, at $744-748$.

23 [1988] FSR 232, at 238.

24 [1963] 3 All ER 413. 


\section{Breach of Confidence in Irish Courts}

Such broad formulations of the doctrine are not, indeed, confined to English authorities, and nor was there any particular reason why they should be, given the heavy dependence of Irish law in this area on English case-law. For example, Lavery, in a leading work on breach of confidence in Ireland, summarises the position thus:

"any situation that involves the misappropriation of information by a person, in circumstances where that person either knows or ought to know that the information should be kept confidential, will be caught by the action." 25

Keane, similarly, took the view, in a leading Irish work on Equity and Trusts published in 1998, that the action covered surreptitious takings of confidential information. ${ }^{26}$

When we turn to the leading Irish Supreme Court authorities, however, we see, in the main, only quite narrow and restrictive formulations of the doctrine of confidence. House of Spring Gardens v Point Blank ${ }^{27}$ concerned a situation in which relations between parties to an agreement to develop and market a bullet-proof vest had broken down, and the defendants subsequently exploited the plaintiff's ideas for their own financial gain. The circumstances were not therefore such as to induce the court to break new ground on the question of the circumstances needed to impose the obligation of confidentiality, since there was clearly both an existing relationship between the parties and a promise (express or implied) of confidentiality. But the formulations of the court contain no dicta suggesting sympathy with a more flexible view of the doctrine. Whilst O'Higgins CJ did describe the quote from Saltman ${ }^{28}$ as "stat[ing] the law in one succinct sentence," ${ }^{29}$ he went on expressly to approve $\mathrm{e}^{30}$ the approach of Costello J, who stated: "It must firstly be decided whether there exists from the relationship between the parties an obligation of confidence." ${ }^{31}$ This suggests not only the need for circumstances imposing such an obligation, but suggests that those circumstances can only be present where there is "a relationship between the parties," a highly restrictive view of the action.

In $N I B \vee R T E$, the facts fell within our third category above, where the defendant acquires information communicated in a relationship of confidence between the plaintiff and another. The plaintiffs operated an investment scheme that appeared to facilitate tax evasion. In excess of 150 customers of the plaintiffs accepted an invitation to participate in the scheme. RTE obtained information about the scheme and about the customers from

25 P. Lavery, Commercial Secrets: The Action for Breach of Confidence in Ireland (Round Hall, 1996), at 109.

26 Equity and the Law of Trusts in the Republic of Ireland (1988) at 349, para 30.05; cited in O'Dell, $\mathrm{n} 8$ above, at 204.

27 [1984] IR 611.

28 That breach of confidence would be made out where "A defendant is proved to have used confidential information, directly or indirectly obtained from a plaintiff, without ... consent ..." (Saltman, n 24 above).

$29 \mathrm{n} 7$ above, at 695.

$30 \mathrm{Ibid}$, at 696.

31 Ibid, at 663 (emphasis added). 
various sources, including, apparently, certain customers and employees of NIB, which it wished to broadcast. The plaintiffs did not claim to be entitled to an injunction restraining the defendant from broadcasting allegations against them that they had been operating a scheme facilitating tax evasion. They sought an injunction preventing the disclosure (including transmission to the world at large) of the names of their customers and the details of their accounts and transactions entered into by them. They claimed that that would constitute a breach of the confidential relationship between the plaintiffs and their customers that would cause them irreparable damage. The defendant accepted that the dissemination of the information would amount to a breach of the confidential relationship in question, but it argued that the breach would be justified by the overriding requirements of the public interest: it submitted that the evidence adduced by it to the High Court provided a strongly arguable case for holding that the public interest in the investigation and exposure of wrongdoing outweighed the requirements of confidentiality. The Supreme Court found that the information concerned a matter of serious public interest due to the wrong-doing revealed and that the interest in publication therefore outweighed the interest in confidentiality. By a 3:2 majority the Court found that the information should be revealed to the public at large.

$N I B$ v RTE thus adds little to the current understanding in Ireland of the elements of breach of confidence, and in particular of the scope of the duty of confidence, since both sides accepted that the material in question was confidential and that an obligation of confidentiality existed (the information acquired had been communicated between two parties in a relationship of fidelity - that between a bank and its customers). Consequently, Lynch J for the majority did not find it necessary to consider the circumstances in which an obligation of confidence may be imposed in general. He simply observed:

"There is no doubt but that there exists a duty and a right of confidentiality between banker and customer as also exists in many other relationships such as for example doctor and patient and lawyer and client. This duty of confidentiality extends to third parties into whose hands confidential information may come and such third parties can be injuncted to prohibit the disclosure of such confidential information." 32

These two decisions, therefore, do nothing to confirm that the developments that have taken place in English law, facilitating the use of confidence as a privacy remedy, will take root in Ireland. As we have seen, the facts provided no opportunity to do so; however, the formulations accepted in House of Spring Gardens in particular are very conservative. Nevertheless, they do not wholly rule out the possibility of such developments in the future. The courts could be viewed in both instances as merely preferring to decide no more than they had to on the basis of the facts before them.

\section{Breach Of Confidence As A Privacy Remedy In Irish Courts?}

Of course, there are noteworthy arguments against the use of breach of confidence as a privacy remedy, in particular the artificiality of the reasoning

$32 \mathrm{n} 7$ above, at 494 . 
that must be employed and the fact that such use distorts an action originally developed to uphold the confidentiality of certain socially or professionally important relationships and to allow those who have expended labour, time and skill the exclusive right to exploit commercially valuable information obtained thereby. ${ }^{33}$ There are also, of course, crucial differences between the concepts of "confidential" (essentially meaning inaccessible) information and information relating to private life. These issues are already causing difficulties for the English courts. ${ }^{34}$ It is not the purpose of this paper to seek to refute these arguments or even to suggest partial solutions to them. ${ }^{35}$ Its much more limited purpose is merely to point out, in pragmatic vein, that flawed as breach of confidence is as a tool for protecting privacy, the reality is that Ireland, like England, has no tort of invasion of privacy. The likely consequence is therefore that the courts will find themselves urged by litigants to develop breach of confidence so as to provide greater protection for privacy since the ECHRA has introduced Article 8 (as an interpretive principle) into Irish law. Whilst, as indicated in the introduction, it is possible that the implied constitutional right to privacy may provide protection against un-authorised use of personal information in some circumstances, in particular in relation to interception of private communications, ${ }^{36}$ it has not been developed so far to provide comprehensive protection against intrusive publications in the media. There is, however, a reasonably persuasive case to be made out that Strasbourg case-law and the general principles it has developed under Article 8 do suggest the need for such a remedy. ${ }^{37}$ Now that the ECHRA is in force therefore, it is quite possible that Irish courts, like their English counterparts, and influenced perhaps by the English case law under the HRA referred to above, will start to develop breach of confidence to fill this lacuna. If this indeed occurs, the focus will be thrown much more sharply than hitherto upon the public interest defence. Before turning to explore this matter, however, it is worth

33 See O'Dell, n 8 above, at 213: "In summary ... the essence of the action of breach of confidence is that it allows the commercial exploitation of information; and, as an incident, may keep information secret. Though there have been extensions (for example to cover domestic or Government confidences) they have been just that, extensions; they do not define the essence of the action, rather the commercial essence of the action conditions these extension." See also ibid, at 211-18.

34 See $\mathrm{n} 20$ above and, generally, Phillipson, $\mathrm{n} 2$ above.

35 It may be argued, however, that the basis of the action for confidence and that of privacy are perhaps not quite so far apart conceptually as O'Dell suggests. O'Dell (n 8 above) accepts, as the best available, Westin's definition of privacy: "the claims of individuals, groups or institutions to determine for themselves when, now and to what extent information about them is communicated to others" (from Privacy and Freedom (New York: Athenaeum, 1967); if this is accepted, then privacy and confidence have a common conceptual basis: both found upon the basic principle of control over information, whether that information is sensitive because personal, or because commercially valuable.

36 Kennedy v Ireland [1987] IR 687 held that an un-authorised telephone tap "was a deliberate, conscious and unjustifiable breach of the applicant's right to privacy" as an implied right under the Irish Constitution (O'Dell, note 8 above, at 229); see also Desmond v Glackin (No 2) [1993] IR 67, at 98, in which Hanlon J referred to a "right to privacy in communications." See also text to $\mathrm{n} 5$ and 6.

${ }^{37}$ See Fenwick and Phillipson, n 18 above $(M L R)$, at 664-667. The main decision indicating this is the Commission's admissibility decision in Earl Spencer v United Kingdom (1998) 25 EHRR CD 105. 
taking a closer look at the ECHRA, in order to determine just how much influence the Convention is likely to have post - "incorporation".

\section{THE EUROPEAN CONVENTION ON HUMAN RIGHTS ACT 2003: A LIMITED INSTRUMENT?}

The main issue with which this paper is concerned is the impact of the ECHRA upon the action for confidence. The ECHRA will clearly affect the common law, ${ }^{38}$ but it should be noted that it appears to impose significantly weaker obligations upon Irish courts to change the common law than does the HRA in the UK context. Section 2(1) enjoins Irish courts that when "interpreting and applying any statutory provision or rule of law" they should do so, "so far as is possible . . . in a manner compatible with the state's obligations under the Convention provisions." This is a very similar provision to section 3(1) HRA. ${ }^{39}$ However, there are two critical differences between the two Acts concerning the courts' duties in relation to the common law. Whilst the ECHRA does at least clarify that the "rules of law" that the courts must interpret compatibly with the Convention if possible include "common law", ${ }^{40}$ the provision in section 5 for making a declaration of incompatibility if the court finds that a given law is incompatible with the Convention, applies not only to statutes (as with the HRA) but also the common law. ${ }^{41}$ In contrast, the judges' duty in section 6(1) HRA to act compatibly with the Convention - something which it now seems reasonably certain includes their function in developing and applying the common law ${ }^{42}$ - is limited only by incompatible primary legislation ${ }^{43}$ not by incompatible common law rules. Therefore an Irish judge, it appears, is required only to seek to develop the common law compatibly with the Convention; if she finds that she cannot, she can only issue a declaration of incompatibility. In contrast, an English judge appears - although this is not yet free from doubt ${ }^{44}$

38 An immediate issue arises as to whether the phrase "common law" used in the Act will actually include breach of confidence. Many scholars and judges would still view it as an equitable doctrine, although it may be noted that Shanley J referred to it in NIB v RTE as "the tort of breach of confidence" (at 474). However it is possible that rules of equity are covered by the Act: the ECHRA uses the phrase "rule of law"; this is explicitly stated to include the common law in s 1(1) but may be read to include equitable actions also. There would seem to be no sensible reason to exclude them.

39 s 3(1) HRA reads: "So far as is possible to do so, primary and secondary legislation must be read and given effect in a way that is compatible with the Convention rights". This of course is subject to the proviso in s 3(2) that incompatible legislation remains valid and of full effect and enforceability.

$40 \mathrm{~s} 1(1)$

41 This is because s 5 includes within it a reference to a "rule of law" that is incompatible with the Convention, and, as noted in the text, the expression "rule of law" is defined in s 1(1) to include the "common law."

42 See eg $A$ v $B$ plc (n 2 above), at 546: "Under section 6 of the [HRA], the court, as a public authority, is required not to act 'in a way which is incompatible with a Convention right.' The court is able to achieve this by absorbing the rights which Arts 8 and 10 protect into the long-established action for breach of confidence."

43 s $6(2)$.

44 See the differing views expressed as the scope of horizontal effect on the common law in Venables and Thompson (n 2 above) at 917, Douglas, (n 2 above) at 993-4, 
- to be obliged to make whatever changes to the common law are necessary to achieve compatibility, given that the HRA does not limit the section 6(1) duty by reference to existing incompatible common law. ${ }^{45}$

Furthermore, the interpretative obligation in section 2(1) ECHRA is itself less strong than that contained in section 3(1) HRA: the duty is expressed to be "subject to rules of law relating to such interpretation and application" - a phrase that appears to make that obligation subject to existing restraints upon how far the judges may develop the common law. In other words, the interpretative obligation in section 2(1) does not, as the duty in section 3(1) HRA does, replace existing rules of interpretation; rather, it takes effect "subject to" them. Thus the obligation on Irish judges to interpret common law compatibly with the Convention is significantly weaker than that lying upon their English counterparts.

There is a further, perhaps even more noteworthy feature of the ECHRA in relation to this point: the deliberate omission of "courts" from those organs of the state obligated to act compatibly with the Convention by section $3(1){ }^{46}$ This weakens the duty on Irish courts further, in comparison to English courts, which, per section 6(3), are explicitly included within the definition of public authorities bound to act compatibly with the Convention rights under section 6(1) HRA. In particular, this omission would appear to suggest that the exercise of judicial discretion in relation, for example, to exclusion of evidence and - significantly for our purposes - the granting of remedies, is not caught by the ECHRA. Thus, in deciding whether, for example, to grant an injunction restraining publication of confidential information, a judge may not be strictly bound by the ECHRA to act compatibly with the Convention. Thus, whilst it may confidently be predicted that the ECHRA will increase the Convention's impact on Irish common law, that impact will be not only indirect, but appears likely to take the form of a general radiating influence rather than strong interpretative effect.

We turn now to the main concern of this article, the public interest defence in Irish law, and the possible future impact of Article 10 ECHR upon it.

1002, 1112, A v B (n 2 above) at 546 and Campbell (n 2 above) at 658 . For discussion see Phillipson, $\mathrm{n} 2$ above, at 729-32.

45 This is indeed the view of Murray Hunt: "The Horizontal Effect of the Human Rights Act" (1998) PL 423. His view is one with which a number of others, including Lester and Pannick ("The Impact of the Human Rights Act on Private Law: The Knight's Move" (2000) 116 LQR 380); and J. Beatson and S. Grosz: ("Horizontality: A Footnote" (2000) $116 L Q R 385$ ) appear broadly to sympathise. H.W.R. Wade, as is well known, sees an even more expansive role for the court under s 6(1): "Horizons of Horizontality" (2000) 116 LQR 217.

46 See the definition of "organs of the state" in s 1(1). This omission is criticised by, eg R. Murphy, "The Incorporation of the ECHR Into Irish Domestic Law" [2001] 6 EHRLR 640, at 655. 


\section{THE PUBLIC INTEREST DEFENCE IN THE IRISH LAW OF BREACH OF CONFIDENCE}

\section{The Public Interest Test - Introduction}

$N I B \vee R T E$ is now the leading Irish decision on the public interest defence in breach of confidence. A significant concern relating to the development of the doctrine of confidence in its own right and in future as a remedy for invasion of privacy, is the fear that the action will pose an unacceptable restraint on media freedom since it prevents the disclosure of truthful facts. The main insurance against this possibility rests with the public interest defence, whereby disclosure of admittedly private or confidential information is permitted if this would serve the public interest. It is necessary first to consider the competing formulations of the public interest/no confidence in iniquity test, and their resolution by the Supreme Court in NIB v RTE.

\section{Non-Iniquity As A Definitional Element Of Confidence?}

Although it has been pointed out above that the decision in NIB $\mathrm{R}$ RTE added little to understandings as to the scope and nature of the duty of confidence, it did clarify the duty in one important sense. The traditional approach to this matter is encapsulated in the maxim that that there is no confidence in iniquity and this point was touched on by Keane $\mathrm{J}$ in $N I B \mathrm{v} R T E$ : it can be taken to mean that the plaintiff cannot pray in aid the equitable jurisdiction of the court to conceal his or her own wrong-doing. ${ }^{47}$ This means that any public interest in disclosure does not operate as a defence; rather, where iniquity is shown, the information does not have the quality of confidentiality (partly on the ground that it is not in the public interest for such wrong-doing to be concealed). Judges sometimes do not acknowledge the implications of relying on the "no confidence in iniquity rule": taken literally it precludes the exercise of balancing the interest in confidentiality against the public interest in disclosure, since if there is no confidentiality in the first place (due to iniquity) then clearly the court would never reach the stage of considering any arguments against keeping the material confidential. Thus to talk of the rule as the basis of the public interest test, as Keane $\mathrm{J}$ did in NIB $\vee R T E$, is to create doctrinal confusion. The other, more prevalent, view is that the public interest justifies a disclosure that would otherwise be a breach of confidence. Following the first view, the non-iniquitous nature of the information would be a necessary element in demonstrating that the ingredients of breach of confidence were present. The judgments in NIB v RTE appear to proceed on the basis of the second view and it can be assumed therefore that it will continue to prevail. For the reasons given in the next section, it is submitted that this view is the more satisfactory one, in readily allowing for a balancing act to take place between different public interests, which also allows for the influence of constitutional and ECHR guarantees of freedom of expression.

47 See eg Gartside v Outram (1856) 26 LJ Ch 113, at 114; and in relation to copyright, Glyn v Weston Feature Film Co [1916] 1 Ch 261. 


\section{The Value Of The Balancing Exercise}

Keane $\mathrm{J}$ (speaking for the minority, but in this case in a passage which was in harmony with the approach of the majority) found:

"The English authorities indicated that the appropriate approach was for the courts to engage in a balancing exercise, described as follows by Goff $\mathrm{LJ}$ in $A G \mathrm{v}$ Guardian Newspapers (No 2) [1990] 1 A.C. 109 at p 282: ‘. . . although the basis of the law's protection of confidence is that there is a public interest that confidences should be preserved and protected by the law, nevertheless that public interest may be outweighed by some other countervailing public interest which favours disclosure ... It is this limiting principle which may require a court to carry out a balancing operation, weighing the public interest in maintaining confidence against a countervailing public interest favouring disclosure." "48

Keane J concluded: "it can be said with confidence that the 'balancing' approach suggested by the English authorities can be adopted in this jurisdiction in a case such as the present." Lynch $\mathrm{J}$ also accepted implicitly that the exercise to be engaged in one of balancing: "the public interest in such publication [relating to wrong-doing] may outweigh the public interest in the maintenance of confidentiality." 49

In terms of the possibility that the doctrine of confidence will broaden in Ireland under the impact of the ECHRA 2003 in order to become something closer to a privacy remedy, the "balancing exercise" formulation, as opposed to a formulation within which "non-iniquity" becomes an aspect of the definitional elements of confidence, is to be preferred. The exercise provides greater flexibility for taking account of the weight of free speech interests, and for balancing them against any privacy interests raised. A formulation in which "non-iniquity" became a definitional element of confidence could invite paternalistic determinations of the court as to the morality of the plaintiff's conduct, without affording him or her a full opportunity to put forward argument as to the weight of the privacy interest involved. For example, a particularly intrusive method of obtaining the information could be taken into account (as in Francome v $M G N$, which concerned an illegal telephone tap $)^{50}$ or the particularly intimate nature of the information revealed. Definitional balancing on the American model has some superficial attractions in relation to conflicts between privacy and free speech, but the methods of balancing the two rights put forward by commentators in relation to Articles 8 and $10^{51}$ (discussed below), and by

$48 \mathrm{n} 7$ above, at 482 .

49 Ibid, at para 44.

50 [1984] 1 WLR 892, at 898.

51 See Phillipson and Fenwick, n 18 above $(M L R)$, at 683-91; H. Rogers and H. Tomlinson QC, "Privacy and Expression: Convention Rights and Interim Injunctions" [2003] EHRLR 37-54. 
some judges in the $\mathrm{UK}^{52}$ provide, we will argue, a more subtle and nuanced method of weighing up the two interests against each other.

The definitive adoption of the "balancing exercise" approach in NIB $\mathrm{v} R T E$ has in this sense opened the door to the movement from confidence towards privacy and from a narrowly drawn notion of "public interest" towards a recognition of the importance of freedom of expression - a movement which has already occurred in English law, largely under the impetus of the HRA. A different or narrower formulation of the exercise would have been likely to stifle that movement. Further, while the notion of "balance" does not provide much guidance as to the method of carrying out the exercise and may appear to be ". . . an invitation to judicial idiosyncrasy" as Gummow J has put it, ${ }^{53}$ the development of that exercise which can now occur, especially under the impetus of the ECHRA, provides criteria which can be used in determining the issues without resorting to judicial commonsense or "adhocery", a matter discussed further below.

\section{The Scope And Content Of The Public Interest Defence After NIB v RTE}

Article 10 of the ECHR had little influence upon the public interest defence in English law prior to the inception of the HRA, ${ }^{54}$ but this has changed markedly in the post-HRA era. The defence as considered in NIB $\mathrm{v} R T E$ is still quite narrow. It is possible that the impact of Article 10 in this context under the ECHRA 2003 will in time follow a similar pattern, although, as discussed above, the influence of Article 10 is likely to be significantly weaker in Irish than in English law, given the weaker form of "incorporation" opted for by the Irish Parliament. However, it is important to point out that the post-HRA authorities in the UK, such as Douglas v Hello! ${ }^{55}$ and $A$ v $B$ plc,,$^{56}$ will themselves be likely to influence the development of the doctrine of confidence in Ireland. Thus the doctrine in Irish law will come under pressure to respond to Article 10 from two directions.

\section{(a) The coverage of the defence: dependency on wrong-doing?}

In English law, the "public interest defence" moved away from the limitation imposed by the link to iniquity: in other words, it allowed a broader range of factors than merely the revelation of misconduct to be taken into account. The House of Lords found obiter in British Steel Corporation v Granada Television ${ }^{57}$ that publication of confidential information could legitimately be

52 See, for example, Re S (a child) [2003] 2 FCR 577; Douglas II (n 2 above), both discussed below.

53 Smith Kline \& French Laboratories Ltd $\mathrm{v}$ Department of Community Services [1990] FSR 617.

54 See eg Jacob J's pre-HRA judgment in Michael Barrymore [1997] FSR 600 which, in a case relating to the unauthorised disclosure of personal information and thus clearly raising both privacy and speech issues, did not once advert to the Convention.

55 [2001] QB 967, at 997.

56 [2002] 3 WLR 542.

57 [1981] AC 1096; [1981] 1 All ER 417 (HL). 
undertaken only where there was misconduct, ${ }^{58}$ but in Lion Laboratories $\mathrm{v}$ Evans $^{59}$ Stephenson LJ said that he would reject the "no iniquity, no public interest rule," agreeing with Lord Denning's statement in Fraser v Evans ${ }^{60}$ to the effect that "some things are required to be disclosed in the public interest in which case no confidence can be prayed in aid to keep them secret and [iniquity] is merely an instance of just cause and excuse for breaking confidence." $W \vee$ Egdell ${ }^{61}$ and Hellewell ${ }^{62}$ also indicate that the defence continued to broaden its focus of concern with the result that the strength of the public interest in question rather than the individual wrongdoing of the plaintiff became the determining factor. In $W \vee$ Egdell, no wrongdoing was relied upon in finding that the medical report relating to the plaintiff's condition should be placed before the appropriate authorities where it was in the public interest to do so. It should be pointed out that there may in certain circumstances be further competing public interests. In $X \vee Y^{63}$ there was found to be a further specific public interest in maintaining confidentiality. A newspaper wished to publish information deriving from confidential hospital records which showed that certain practicing doctors were suffering from the AIDS virus. In granting an injunction preventing publication, Rose $\mathrm{J}$ took into account the public interest in disclosure, but weighed it against the private interest in confidentiality and the public interest in encouraging AIDS patients to seek help from hospitals, which would not be served if it was thought that confidentiality might not be maintained. It may be concluded that these rulings accepted the possibility of the existence of a broadly-based public interest defence, not based on iniquity or indeed on any form of wrong-doing by the plaintiff.

In NIB $\vee$ RTE at first instance, Shanley $\mathrm{J}$ found that it would be unwise to define the boundaries of the public interest exception, but held that "misdeeds of a serious nature and importance to the country will justify disclosure." ${ }^{\circ 4}$ But he also went on to offer a more expansive approach to the defence, commenting that, "the countervailing public interest is that of the public being kept informed on matters which are of real public concern." $\mathrm{He}$ added: "A further public interest, of course, is the public interest in preserving freedom of expression, which ... is enshrined in Article 40.6.1 of [the Irish Constitution]." On the facts he found that disclosure was justified.

In the Supreme Court the minority and majority judges agreed that there should be disclosure where there has been wrong-doing, although they disagreed as to whether that disclosure should be only to the proper authorities (as the minority held) or should extend to publication to the public at large. Lynch $J$ in the majority said: "There is also a public interest

58 See further: Cripps (1984) 4 OJLS 184 on the public interest defence.

59 [1985] QB 526, at 537.

60 [1969] 1 QB 349, at 362.

61 [1990] Ch 359; see also $X$ v $Y$ [1988] 2 All ER 658, and dicta of Lord Goff in $A G$ v Guardian Newspapers (No 2), n 9 above, at 659. Egdell concerned a decision to breach confidence by placing details of the plaintiff's mental disorder before the appropriate authorities because it was thought that he constituted a risk to the public.

62 [1995] 1 WLR 804.

63 [1988] 2 All ER 648.

$64 \mathrm{n} 7$ above, at 475. 
in defeating wrong-doing and [this] . . . may outweigh the public interest in the maintenance of confidentiality." "Wrong-doing" is a broad term but it appears to take the British Steel Corporation v Granada Television rather than the Lion Laboratories line. Thus is it is quite a narrow formulation of the defence compared to that accepted in English law even pre-HRA.

Lynch $\mathbf{J}$ appeared to introduce a further qualification: at one point in the judgment he said:

"There is also a public interest in defeating wrong doing and where the publication of confidential information may be of assistance in defeating wrong-doing then the public interest in such publication may outweigh the public interest in the maintenance of confidentiality." 65

But when he came actually to decide the case before him, the judge relied upon a much more general formulation:

"I certainly agree that the defendant should furnish its information to [the proper] authorities and especially if it is asked for such information by such authorities, but the allegation which it makes is of serious tax evasion and this is a matter of genuine interest and importance to the general public and especially the vast majority who are law abiding tax payers and I am satisfied that it is in the public interest that the general public should be given this information." 66

The italicized qualifying words used in his first formulation of the defence went largely to its scope; the second formulation could be viewed as relating to the extent of the disclosure. If his first formulation were to be relied upon as delimiting the scope of the defence it would narrow the defence quite considerably. It appears to allow publication only where that would assist in defeating wrong-doing, and since publication of matter relating to wrongdoing is usually likely to have quite a tenuous connection with defeating it, this formulation would severely restrict the circumstances in which publication of confidential material may be permissible in the public interest. However, although Lynch J's formulations of the defence are not free from ambiguity, it is arguable that his second formulation could be read as relating to both scope and extent and therefore as indicating that a broad formulation - based on wrong-doing but also on the strength of the public interest would support publication to the public at large, where those tests were satisfied.

Keane $\mathrm{J}$ in the minority appeared at one point in his judgment to adopt a broader formulation of the defence. Having reviewed the English authorities, he noted that, following the more recent ones, in particular Lion Laboratories (concerning disclosure of information about the inaccuracy of the Intoximeter used to test for drink driving), the public interest defence could reach beyond misconduct and cover information disclosing a "danger to the public". The term "danger" is ambiguous - related to Lion Laboratories it could be viewed as covering the danger of a miscarriage of

65 Ibid, at 494 (emphasis added).

66 Ibid, at 495. 
justice, since drivers could be convicted of drink-driving offences on the basis of inaccurate readings of the level of alcohol in their bloodstream. But in its natural meaning the term has an exclusionary tendency since it could be viewed as connoting some sort of physical danger. However, since Keane J relied on Lion Laboratories it may be suggested that he was referring to matters of strong public interest where sections of the public at large or most of the public could be endangered or placed at risk in some way by the activity revealed by the information in question. (On one view, of course, Lion Laboratories could be seen as referring narrowly to physical danger since had a driver been stopped but found wrongly to be under the limit an accident could subsequently have occurred. However, this is not the view that is taken of its ratio in England, as the discussion above demonstrates.) In his conclusion, Keane J, referring to the authorities that "should be followed in this jurisdiction," reverted to a narrower formulation of the defence: "the authorities . . . make it clear that where someone is in possession of confidential information establishing that serious misconduct has taken place or is contemplated, the courts should not prevent disclosure ..."67 Thus his earlier finding was not reflected in his conclusion. However, the former dicta suggested some sympathy with the broader formulation of the defence. A leading commentary on the decision viewed these tentative pointers towards such a formulation as of particular significance, remarking: "it is to be hoped that an Irish court, when asked to address the issue squarely, will follow his dictum." 68

If this broader formulation of the defence is accepted in future in the Irish courts it would accord with Lion Laboratories and with the later English authorities, but not with the majority view in NIB $\mathrm{v} R T E$ as expressed by Lynch $\mathbf{J}$ - even if one omits the limiting words referring to publication as having to be of "assistance" in defeating wrong-doing. However, Lynch J did not need to advert to the wider view of the defence on the facts before him - since wrong-doing had clearly occurred-and therefore the way is still open to develop it on these broader lines. We would suggest that this wider formulation is to be preferred, since it is more consistent with the principles one would expect to be at stake in a test based on the "public interest." The most compelling matter under such a test would be expected to be the depth of that interest - in the sense that the information conveys serious and weighty matters of legitimate concern to the public, rather than the degree of culpability of the plaintiff. Clearly also, a broader formulation of the test tends to afford greater weight to the freedom of the media as watchdog bodies with a duty to inform the public of matters of public interest; since Article 10 is now afforded further effect in Irish law under the ECHRA, adoption of a test which is Article 10-friendly is a step in the direction of ensuring greater harmony between this area of the law and the Convention as required by section 2 ECHRA. Such a stance would also accord with the

${ }^{67}$ Ibid at 487 . The full quotation is: "The authorities to which I have already referred and which, I am satisfied, should be followed in this jurisdiction, make it clear that where someone is in possession of confidential information establishing that serious misconduct has taken place or is contemplated, the courts should not prevent disclosure to persons who have a proper interest in receiving information."

68 See P. Lavery, "National Irish Bank v RTE - the Defence of Public Interest in Irish Law" (1998) CLP 111, at 114. 
preservation of freedom of expression in accordance with Article 40.6 of the Constitution.

\section{(b) The impact of Article 10 - moving towards even broader formulations of the Irish public interest test?}

A number of Strasbourg decisions could be cited to illustrate the likely impact of Article 10 on the public interest defence, but the decision in Fressoz and Roire v France, ${ }^{69}$ illustrates the point particularly clearly, in part because of the similarity of the facts of the case to those of NIB $\vee R T E$.

The applicants in Fressoz were journalists. During a period of industrial unrest within the Peugeot motor car company, caused by the refusal of the management, led by M. Calvet, to award pay increases to the workforce, they published an article revealing the very large pay rises awarded during that period to M. Calvet himself. They proved the truth of this story by quoting figures from, and reproducing part of, M. Calvet's tax return, which had been sent to them anonymously. A criminal investigation relating to the theft of the tax returns by employees at the tax office was launched, but no-one there was charged. The applicants, however, were convicted of the offence of handling confidential information obtained through a breach of professional confidence by an unidentified tax official and of handling stolen photocopies of M. Calvet's tax assessment; they were fined around $£ 1,000$ and $£ 500$ respectively. They applied to Strasbourg, alleging a breach of Article 10 ECHR.

The key issue under Article 10 was whether, as the applicants claimed, the article revealed matters of serious public interest. The Court found that it did:

"The article was published during an industrial dispute widely reported in the press - at one of the major French car manufacturers . . . The article showed that the company chairman had received large pay increases during the period under consideration while at the same time opposing his employees' claims for a rise. By making such a comparison against that background, the article . . . was not intended to damage Mr Calvet's reputation but to contribute to the more general debate on a topic that interested the public (see, for example, Thorgeir Thorgeirson v Iceland (1992) A 239, page 28). .70

The Court continued:

"Not only does the press have the task of imparting information and ideas on matters of public interest: the public also has a right to receive them ... That is particularly true in the instant case, as issues concerning employment and pay generally attract considerable attention. Consequently, an interference with the exercise of press freedom cannot be

69 (2001) 31 EHRR 2.

$70 \mathrm{Ibid}$, at para 50. 
compatible with Article 10 of the Convention unless it is justified by an overriding requirement in the public interest." ${ }^{\prime 1}$

In this case, far from there being such an overriding interest, there were particular reasons why the arguments against disclosure were weak: the information was not strictly confidential, since it was available on public record ${ }^{72}$ it did not, moreover, fall within $\mathrm{M}$ Calvet's private life; ${ }^{73}$ thus Article 8 was not engaged as a countervailing consideration to the applicant's claim under Article 10. However, the case remains illuminating as a contrast to the decision in NIB v RTE. First of all it clearly illustrates (although this barely needs re-affirming) that in considering restrictions on speech, a court applying Article 10 must go beyond considering whether the publication in question discloses serious wrong-doing which the public interest would benefit from having revealed. It is clear that in this case there was no "wrong-doing" (except perhaps in a political sense) to be revealed: there was no fraud, crime or anti-social behaviour in question. The information was important, however, insofar as it contributed to a serious public debate as to the management of Peugeot and, in particular, alleged unfairness and greed on the part of the management. A court applying a narrow public interest test which insisted that there must be a public interest served by the revelation of serious wrong-doing would therefore have presumably come to the conclusion that in this case publication should not be permitted - the reverse of the conclusion unanimously reached by the European Court of Human Rights. Fressoz thus establishes in the clearest possible way that the requirement of serious wrong-doing, as an essential element to the public interest test, or even that of a "danger" to the public should be dropped by the Irish Courts if they are inclined to use section 2 ECHRA to bring Irish law fully into line with the demands of Article 10, as interpreted in Fressoz.

It may be therefore said that three possible formulations of the defence are now evident: first, that based on the plaintiff's culpability in relation to matters of serious public concern; second that based on revealing a "danger" to the public; finally, that based on matters of serious public concern where no such danger is evident - as in Fressoz. Obviously the final one is by far the broadest and encompasses the other two. The jurisprudence of the English courts demonstrates that they have moved through all three formulations and at present adhere to the third. Indeed, as discussed below, they have, post-HRA, arguably moved beyond the third towards embracing publication on extremely flimsy public interest grounds. The Irish courts, as $N I B$ v RTE confirms, adhere at present to the first, although they show a tentative receptivity towards the second.

\section{(c) Extent of the disclosure}

Fressoz also illustrates, we would suggest, that Article 10 requires a much more generous attitude towards the circumstances in which disclosure may be made in the press, as opposed merely to the proper authorities; again this

71 Ibid, at para 51 (emphasis added).

72 Ibid, at para 53.

$73 \mathrm{Ibid}$, at para 50. This was because it concerned the financial affairs of a public figure. 
is a matter from which Irish courts may also draw guidance from English decisions, including those made prior to the HRA.

In $W \mathrm{v}$ Egdell ${ }^{4}$ the notion of wrongdoing was not relied upon in finding that the medical report relating to the plaintiff's condition should be placed before the appropriate authorities where it was in the public interest to do so. But it should be noted that this decision placed some limitations on the ability of the public interest defence to afford protection to press freedom: it was found that it might sometimes be appropriate to pass information to a particular body rather than disclosing it to the public at large. ${ }^{75}$ In $N I B$ v $R T E$ the minority judges considered that disclosure should be limited to the revenue authorities, and that in terms of the two interest involved there was no need for disclosure to the public at large: in other words, the public interest in confidentiality outweighed that in relation to wrong-doing as far as wider disclosure went. But the majority, weighing up the two interests, favoured wider disclosure on the basis of the seriousness of the behaviour, taking into account the fact that the public as a whole has an interest in tax evasion.

It is worth noting, under the minority view as to the extent of the disclosure, that if permissible disclosure in such instances was to be confined to particular bodies - usually state regulators - then investigative journalism would tend to be stifled since the media would have little interest in acting in effect - as the unpaid investigative arm of the state. Clearly, it is the function of the media to root out abuses, but it is a more important function, as the European Court of Human Rights pointed out in Fressoz and on numerous other occasions, to inform the public. Thus it could be argued that there is a public interest in allowing wider disclosure (although clearly it would not prevail in every instance) for this reason in itself. The impact of the ECHRA may tend to broaden the thinking of Irish judges in cases of this nature in terms of acceptance of a human rights culture. Although the outcome in NIB v RTE was a media-friendly one, the reasoning is not: the judges of the Supreme Court did not at any point advert to the value of freedom of expression or to the significance of the media in terms of rooting out abuses of power or corruption as in the instance under consideration. Lynch J seemed concerned merely with the culpability of the plaintiff and its clients, not with the importance of free expression more generally. Ironically, although Keane J's judgment appeared to take some account of free expression values in the sense that his formulation of the public interest test was the broader one, he then formulated a test for the extent of disclosure which was very narrow and which would tend, as pointed out above, to discourage investigative journalism.

74 [1990] Ch 59.

75 Where disclosure has been said to be in the public interest because it exposes particular criminal or anti-social behaviour or reveals some specific risk to public health, it has been held that this will not always justify disclosing the matter in the press: see Francome [1984] 1 WLR 892; Initial Services Ltd v Putterill [1968] 1 QB 396, at 405-06, per Lord Denning; AG v Guardian Newspapers (No 2) [1990] 1 AC 109, at 269, per Lord Griffiths; ibid, at 282, per Lord Goff; ibid, at 177, per Sir John Donaldson in the Court of Appeal. 


\section{WEIGHING UP MEDIA FREEDOM AGAINST CONFIDENTIALITY/PRIVACY - HOW TO CONDUCT THE BALANCING EXERCISE}

It is of interest to ask by what reasoning process in their decision in NIB v $R T E$, the Supreme Court determined (a), that the public interest in knowing of the tax evasion scheme and those involved in it outweighed the interest in confidentiality; and (b), that disclosure should be to the public at large. As regards (a), Lynch J said: "the allegation which it makes is of serious tax evasion and this is a matter of genuine interest and importance to the general public and especially the vast majority who are law abiding tax payers." $\mathrm{He}$ also found:

“. . greater consideration must be given to the publication of the names of and related information about customers and their accounts. [The evidence - the affidavit] establishes a strong prima facie case that at least the greater number of the Clerical Medical Insurance Company Limited policy investors were doing so for the purposes of tax evasion ..."

- and held that no injunction should be issued to protect their identities. As regards (b), Lynch $\mathbf{J}$ agreed that the information should be given by the defendants to the Inland Revenue, but also said: "I am satisfied that it is in the public interest that the general public should be given this information."

Arguably, this conclusion was quite clearly justified here, since the case concerned criminal activity. However, the reasoning affords no indications as to how to conduct the balancing exercise in less clear-cut cases. If the public interest defence continues to broaden in Ireland as it has done in England, methods of balancing the interests in question sensitively against each other in the hard cases will have to be developed. However, the precise methodology to be used will vary, depending upon the nature of the interest in preventing disclosure in the particular case.

At present, once the applicant has established a prima facie breach of confidence, the onus switches to the defendant to establish that there is a sufficiently strong public interest to override the duty of confidentiality and allow publication. This was precisely the approach taken in NIB $\mathrm{R} R E$. The court took confidentiality as its starting point and viewed freedom of expression as - in effect - an exception to it, under the rubric of the public interest test. The words "in effect" are used advisedly: none of the judges in the Supreme Court expressly adverted to the effects of Article 10 of the Convention or to Article 40.6 of the Constitution, and this in spite of the fact that the remedy sought by the plaintiff amounted to prior restraint of the media. Now that Article 10 has been afforded further effect under the ECHRA 2003, the structure of this reasoning ought to change, but we would suggest that precisely how it will change will depend upon whether the court is engaged in weighing up confidentiality or privacy rights against freedom of expression.

\section{Cases Concerning Confidentiality Versus Freedom Of Expression}

If what is in issue is confidentiality but not privacy interests (for example in a case concerning commercial secrets) the onus will lie on the applicant to show that confidentiality, admittedly a legitimate aim under paragraph 2 of 
Article 10, justifies restricting expression. Thus confidentiality would be viewed as an exception - to be "narrowly interpreted"76 - to the primary guarantee of freedom of expression. To make out an exception, as is well known, it must be shown that there is a pressing social need to restrain publication and that the measures taken are proportionate to the legitimate aim of maintaining confidentiality. The latter factor will demand that particularly close attention be paid to the question whether an injunction representing a far more serious restriction on speech - should be granted, or whether the plaintiff should be left to his or her remedy in damages and or/an account of profits. As is well known, the European Court of Human Rights has found that prior restraint demands the "most careful scrutiny." 77 The term "public interest" defence would no longer appear to be appropriate unless the courts took the view that issues of public interest could be viewed separately from those of freedom of expression - since, as seen in the judgment of in Fressoz, confidentiality becomes a defence to the media's claim of freedom of expression, rather than the other way around.

The Irish Courts in some cases have indeed already arrived at a position similar to that just described. For example, in Attorney General for England and Wales $\mathrm{v}$ Brandon Books, ${ }^{78}$ Caroll $\mathrm{J}$ held: "in my opinion there is prima facie a constitutional right to publish information and the onus rests on the plaintiff to establish in the context of an interlocutory application that the constitutional right of the defendant should not be exercised." What was "at stake [was] the very important constitutional right to communicate now and not in a year or more."

As O’Dell puts it, O’Hanlon J in Maguire v Drury ${ }^{79}$ “all but announced a rule against prior restraint": ${ }^{80}$

"It appears to me that the balance of convenience [in deciding whether to grant an injunction] should also take into account the general undesirability of holding up - perhaps for years the publication of material when the ultimate decision is likely to be that it was quite lawful to publish. Otherwise the interlocutory injunction could be used effectively to encroach in a significant manner on the freedom of the press." 1

However, it is clear that such an approach was not even adverted to in NIB v $R T E$, despite the fact that the case clearly raised the issue of media freedom. It is therefore by no means firmly established in Irish law.

\section{Cases Concerning Privacy Versus Freedom Of Expression}

If instead, the information, as well as being confidential, also relates to private life under Article 8, then it is clear that a different approach from that seen in cases such as NIB v RTE should be followed under the ECHRA in

76 Sunday Times v UK (1979-80) 2 EHRR 245.

77 See Observer and Guardian v UK (1991) 14 EHRR 153, at para 60.

78 [1986] IR 597.

79 [1995] ILRM 108.

80 O'Dell, $\mathrm{n} 8$ above, at 211.

81 Ibid, at 116. 
order to avoid denying privacy its status as a Convention right. ${ }^{82}$ This can be briefly illustrated by examples from post-HRA English decisions in which the courts have grappled with the issue of how to deal with cases that raise issues under both Articles 8 and $10 .^{83}$

In Venables and Thompson, counsel representing the press argued:

"There was a presumption in favour of freedom of expression, which was a primary right in a democracy. It was not a question of a balancing exercise by the court. A balancing exercise would presume that the scales started in equal balance. That was not the correct approach." ${ }^{4}$

In Theakston, Counsel similarly submitted that:

“. . . the court should follow the approach set out in Sunday Times v UK (1979) . . . in which the [European Court of Human Rights] said that the Court in deciding whether a given interference with free expression was necessary in a democratic society 'is faced not with a choice between two conflicting principles, but with a principle of freedom of expression that is subject to a number of exceptions which must be narrowly interpreted." 85

Such propositions can indeed apparently be found in numerous English dicta of the highest authority. In Reynolds $\mathrm{v}$ Times Newspapers ${ }^{86}$ for example, Lord Steyn pronounced:

"The starting point, is now the right of freedom of expression, a right based on a . . . higher legal order foundation. Exceptions . . . must be justified as being necessary in a democracy. In other words, freedom of expression is the rule, and regulation of speech is the exception requiring justification."

The difficulty here is that in following the common law right to freedom of expression established in Reynolds, Derbyshire ${ }^{87}$ and Simms, ${ }^{88}$ which, even before incorporation, had raised freedom of expression to the status of a genuine constitutional right, rather than merely a residual liberty, the courts have failed to appreciate a key point. These cases were not decided in the context of the conflict of freedom of expression with another fundamental right; thus they cannot be applied simpliciter to circumstances in which such a clash is the very issue that the court must resolve. As the authors pointed out, before the coming into force of the HRA:

82 Such an approach would also take account of the impact of the English post-HRA case-law.

${ }^{83}$ For a full account, see Phillipson, n 2 above, at 748-58. We draw on this material in the section that follows.

$84 \mathrm{n} 2$ above, at 913.

$85 \mathrm{n} 2$ above, at 31.

86 [1999] 4 All ER 609, at 629.

87 Derbyshire County Council v Times Newspapers [1993] AC 534.

$88 R$ v Secretary of State for the Home Department, ex parte Simms [2000] 2 AC 115. 
"If [The Sunday Times case] approach were to be applied in domestic privacy cases, the result would be that privacy would lose its Convention status as a fully-fledged right, becoming instead merely a narrowly interpreted exception to the right of freedom of expression. Such an approach, we would argue, could not be right. It would introduce a striking asymmetry whereby the protection of the right to privacy would have to be justified as necessary in a democratic society, while the claims of free speech would be simply assumed. While the European Court has not addressed the matter explicitly, it must be the case that where a restriction on a Convention right is justified not as serving one of the societal interests the Convention enumerates, such as economic well-being or protection of morals, but in order to protect another primary Convention right, a different approach should be followed." 89

To put it in another way, to treat privacy rights under Article 8 in the same way as the societal interests enumerated in Article 10(2), simply collapses the basic scheme of the Convention which, as a human rights treaty is, axiomatically, to afford human rights a special status over other interests. Arguably, the post-HRA decisions in $A$ v B,$^{90}$ Theakston $M G N^{91}$ and Mills v News Group Newspapers ${ }^{92}$ all fell into this trap, ${ }^{93}$ but the problem is most clearly illustrated by the approach the court took in the well-known decision of Venables and Thompson, which concerned an application for an injunction contra omnes to prevent publication of the details of the identity and whereabouts of the two juvenile killers of Jamie Bulger. Butler Sloss P stated:

"The onus of proving the case that freedom of expression must be restricted is firmly upon the applicant seeking the relief. The restrictions sought must . . . be shown to be . . . justifiable as necessary to satisfy a strong and pressing social need, convincingly demonstrated, to restrain the Press . . . and proportionate to the legitimate aim pursued." 94

Her Ladyship went on:

"I am satisfied that I can only restrict the freedom of the media to publish if the need for those restrictions can be shown to fall within the exceptions set out in Article 10(2). In considering the limits to the law of confidence, and whether a remedy is available to the claimants within those limits, I must interpret narrowly those exceptions." 95

89 Phillipson and Fenwick, n 18 above (MLR), at 686.

$90 \mathrm{n} 2$ above. While certain general passages in the judgment suggest a more balanced approach, the way that the conflict between the two rights was resolved in the particular case did indeed exemplify this tendency.

91 n 2 above.

92 n 2 above.

93 See Phillipson, $\mathrm{n} 2$ above, at 751-52.

$94 \mathrm{n} 2$ above, at 921.

$95 \mathrm{Ibid}$, at 931 (emphasis added). 
The point missed here, however, is that the relevant exceptions here were other Convention rights - the rights to life, to freedom from torture or inhuman treatment and to privacy. In other words, the judge regarded herself as being bound to make sure that Convention rights other than Article 10 were "narrowly interpreted" and, crucially, that claimants wishing to enjoy those other Convention rights should only lawfully be allowed to do so if they could show that this was "necessary." The judgment takes us to the bizarre situation in which a claim of Article 10 automatically relegates all other Convention rights - including the right to life and to freedom from torture - to the status of narrowly construed exceptions. Such an approach, giving freedom of expression presumptive priority over all other Convention rights, amounts to a radical distortion of the basic Convention scheme.

However, the need for a different approach has started to find acknowledgment both in the courts and by other academic commentators on the HRA. In Douglas, the argument as to the structural priority to be given to freedom of expression was evidently put to the court and - in perhaps the most important aspect of the judgments - it was rejected. This is in spite of the fact that section 12(4) HRA instructs the courts, inter alia, to have "particular regard" to freedom of expression. But Sedley LJ's reasoning on this point was emphatic:

"The European Court has always recognised the high importance of free media of communication in a democracy, but its jurisprudence does not - and could not consistently with the Convention itself - give Article 10(1) the presumptive priority which is given, for example, to the First Amendment in the ... United States. Everything will ultimately depend on the proper balance between privacy and publicity in the situation facing the court." 96

Some support has very recently been given to this view in the judgment of Simon Brown LJ in Cream Holdings Ltd $\mathrm{v}$ Bannerjee ${ }^{97}$

"It is one thing to say . . . that the media's right to freedom of expression, particularly in the field of political discussion "is of a higher order" than "the right of an individual to his good reputation"; it is, however, another thing to rank it higher than competing basic rights."

Or, as Lindsay $\mathbf{J}$ put it in Douglas II, “there is no 'presumptive priority' given to freedom of expression when it is in conflict with another Convention right." 98

What, therefore, would be the better approach? We have argued previously that, instead of treating Article 8 merely as an exception to Article 10, requiring the applicant to show that interferences with the latter were necessary and proportionate, the court, having undertaken that inquiry,

$96 \mathrm{n} 2$ above, at 1004.

97 [2003] EWCA Civ 103, at para 54. The case concerned an application for an interim injunction to restrain commercially confidential material and in particular the construction of s 12(3) HRA, which sets out a new test for the grant of relief that affects freedom of expression.

98 n 2 above, at para 185(v). 
should then go on to a further stage with the rights reversed in position. At this point:

\begin{abstract}
"the speech interest [would be] treated as an exception to the primary right to respect for privacy under Article 8; the same enquiries as to necessity and proportionality could then be made from this opposing perspective. In this way, useful insights could be gleaned by asking, for example, both whether the publication in question was more intrusive than was necessary to its legitimate aim of provoking discussion on matters of public interest .... and, conversely, whether the remedy sought by the plaintiff went further than was necessary in order to protect the legitimate privacy interest. The claims of both parties would thus be subject to a searching, but balanced examination." 99
\end{abstract}

Such an approach has recently been endorsed by leading media law practitioners Hugh Tomlinson QC and Heather Rogers, who argue that the approach of the courts to date neglects the need to conduct such a "parallel analysis" into the necessity of infringing the claimant's Article 8 right. ${ }^{100}$ It has also received some judicial endorsement: Sedley LJ remarked in Douglas that both Articles ( 8 and 10) were qualified by each other and that when balancing the two against each other, "the outcome ... is to be determined principally by considerations of proportionality." 101 In Harris v Harris, ${ }^{102}$ although there was no detailed consideration of the balancing exercise between Articles 10 and 8, Munby $\mathrm{J}$ accepted that the approach adopted by Sedley LJ should be followed. ${ }^{103}$

Further very significant support for this approach may be found in the approach of Lady Justice Hale in the Court of Appeal in $R e S,{ }^{104}$ in a case concerning the question of imposing reporting restrictions under the inherent jurisdiction of the court in order to protect the privacy of a child. Lady Justice Hale, who gave the leading judgment, found that the lower court had adopted the wrong approach. In that court it had been assumed that press freedom would be afforded primacy and that the Article 8 rights of the child would figure merely as exceptions under Article 10(2). Having repudiated that approach, Lady Justice Hale then went on to consider the proportionality of the proposed interference with freedom of expression. She had to consider under Article 10(2) what restriction, if any, was needed to meet the legitimate aim of protecting the rights of the child. If prohibiting publication of the family name and photographs was needed, the court had to consider how great an impact that would in fact have upon the freedom protected by Article 10 in the particular circumstances of the case. She then went on to consider the matter from the perspective of the child's Article 8 rights, media

99 Fenwick and Phillipson, n 18 above $(M L R)$, at 687.

100 n 51 above, at 50-52.

$101 \mathrm{n} 2$ above, at 1005 (emphasis added).

102 [2001] 2 FLR 895.

$103 \mathrm{Ibid}$, at para 384.

104 [2003] 2 FCR 577; (2003) 147 SJLB 873. The case concerning the possibility of restraining media reports which would have identified the child's mother, who was standing trial for the murder of his brother. It was thought that the publicity would lead to the creation of greater distress for an already very vulnerable child. 
freedom figuring this time as an exception to them under Article 8(2). In considering the proportionality of the proposed interference with the right of the child to respect for his private and family life, the judge had to take account of the magnitude of the interference proposed. Lady Justice Hale came to the conclusion that since the first instance judge had not considered each Article independently, and so had not conducted the difficult balancing exercise required by the Convention, the appeal should be allowed, in order that the exercise could be properly carried out by the first instance Family Division court. The two judges in the majority disagreed, finding that although the balancing exercise outlined by Lady Justice Hale should have been carried out, the result reached at first instance - that the restraining order preventing publication should be discharged - would have been reached even if it had been properly carried out. They considered that the first instance judge had not carried out the exercise correctly, but had had factors relevant to the question of proportionality under Article 8 sufficiently in mind.

The detailed practical consequences of such a reasoning process in privacy cases are explored elsewhere ${ }^{105}$ and need not be repeated here. What is perhaps more important to note is that this notion of balancing constitutional rights on a case-by-case basis, using proportionality as the key tool in so doing, has already been arrived at independently by academic commentators upon the Irish constitution. O'Dell sees such a process at work in, for example, Magee v $O^{\prime}$ Dea $^{106}$ and Burke v Central Independent Television, ${ }^{107}$ in which he suggests that O'Flaherty CJ saw the issue as one of balancing. In Shaw, ${ }^{108}$ a contrary approach, of assigning rights to an a priori hierarchy, was seemingly suggested:

"If possible, fundamental rights under a Constitution should be given a mutually harmonious application, but when that is not possible, the hierarchy or priority of the conflicting rights must be examined both as between themselves and in relation to the general welfare of society. This may involve toning down or even putting into temporary abeyance a particular guaranteed right so that, in a fair and objective, way, the more pertinent important right in a given set of circumstances may be preferred and given application."

However, as O'Dell points out, although the language of hierarchy is used, in reality the question is one of balancing: "it is not the mechanical ascription of immutable precedence of one right over the other," but instead an assessment "in a given set of circumstances" of which of the conflicting rights must be put "into temporary abeyance." Under this approach "the precedence of the rights changes according to the circumstances, which means that it is not a hierarchy at all, but rather the result of an individuated balancing process." 109 Thus he cites McCarthy $\mathrm{J}$ in Attorney General $v$ X:110

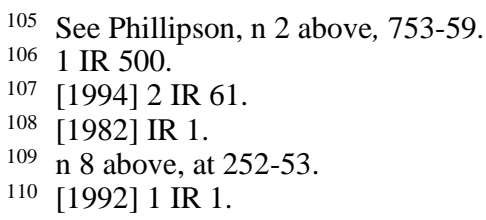


"I would prefer to seek harmony between the various rights guaranteed and to reconcile them to each other rather than rank one higher than another."

O'Dell then arrives at the very same conclusion as that suggested above in the context of balancing Articles 8 and 10: "Presumably, the doctrine of harmonious interpretation further requires that the exercise of each right restrict the other as little as possible: this is the doctrine of proportionality."111 He suggests that this approach was seen in Heaney v Ireland, ${ }^{112}$ and summarises it thus:

"The doctrine, by requiring that the least restrictive invasion of any given right be adopted so as to respect the other, would therefore ensure that any precedence which is to be given to one right over the other as a consequence of balancing is only so much as is strictly necessary in the circumstances." 113

Thus the correct approach towards the resolution of conflicts between Articles 8 and 10 ECHR is already indicated in previous Irish authority, English decisions and academic commentary in both jurisdictions. It is to be hoped that this approach will therefore be followed by Irish courts should the development of breach of confidence in Ireland throw up conflicts between speech and privacy interests, as this paper has suggested is highly likely, or indeed, if any other common law or interpretative constitutional developments give rise to a workable privacy action.

\section{The Public Interest Test And Article 10: Related Or Separate Enquiries?}

There remains the issue of how the Irish courts are to weave Article 10 into their existing consideration of the public interest in publication. ${ }^{114}$ It should be noted at the outset that introducing Article 10 into the equation, as a counterpoint to Article 8, complicates the issue on the theoretical level. Whereas the public interest defence is by its nature wholly consequentialist (looking to the benefits of disclosure - or the harm to be averted by it), a freedom of expression argument relies at least in part upon the inherent right of the individual to communicate, regardless of circumstances. For this reason, it raises a conflict with privacy - another inherent right - in a far more acute form. At its crudest, the court is confronted by a position in which one party is simply entitled to his privacy, and the other is simply entitled to invade it, by exercising his right to freedom of expression. The solution to this problem, we suggest, lies in recognition of the fact that the Convention rights in fact exhibit what Mullender has termed "qualified

$111 \mathrm{n} 8$ above, at 252.

112 [1994] 3 IR 593.

$113 \mathrm{n} 8$ above, at 254.

114 This issue is explored further in G. Phillipson, "Judicial Reasoning in Breach of Confidence cases under the Human Rights Act: Not Taking Privacy Seriously?" [2003] EHRLR (Privacy Special) 54, at 60-72. We draw on material from this article in what follows. 
deontology":115 whilst they purport to uphold a set of human rights established regardless of consequences, they allow for their restriction by reference to consequentialist considerations, in pursuance of a legitimate aim and in a manner proportionate in the circumstances. Moreover, since Articles 10 and 8 are both qualified in favour of each other ${ }^{116}$ (both recognise "the rights of others" as a legitimate aim for limiting the primary right), they also provide a method of resolving competing individual rights. As we have previously argued, such resolution may be found through recognition of the rights' mutual supportiveness as upholding certain, more basic values, ${ }^{117}$ and then through giving consideration to which of those values are more strongly engaged by which right in the particular case. Again, this point has already been taken in relation to balancing constitutional rights in Ireland. O'Dell suggests that, when conducting a balancing exercise between privacy and speech, "the courts should have regard to the justifications for each of the rights, and the weight each carries in the constitutional order." 118

There is a persuasive case to be made out at the theoretical level that speech consisting of reportage of the personal lives of celebrities receives little or no support from any of the values underlying freedom of expression. ${ }^{119}$ It is unrelated to the self-government rationale, ${ }^{120}$ cannot generally further the search for truth ${ }^{121}$ and runs directly counter to the arguments from autonomy ${ }^{122}$ and self-development: ${ }^{123}$ in being calculated to deter those in the

115 See R. Mullender, "Theorising the Third Way: Qualified Consequentialism, the Proportionality Principle and the New Social Democracy" (2000) 27(4) Journal of Law and Society 493.

116 As Sedley LJ remarked in Douglas, n 2 above, at 1005.

117 These include autonomy and self-development, both of which are recognized as underlying justifications for both freedom of expression and privacy; moreover, the right to privacy to develop one's thoughts can be seen as an essential precursor to free expression; on this, see E. Bloustein, "Privacy as an Aspect of Human Behaviour: an answer to Dean Prosser" (1964) 39 NUULR 962; A. Westin, Privacy and Freedom (Atheneum: New York, 1970), at 34. For further discussion, see Fenwick and Phillipson, n 18 above (MLR), at 682-91.

$118 \mathrm{n} 8$ above, at 255

119 For the full argument, see Phillipson and Fenwick, n 18 above (MLR), at 680-85, 689-70. See also E. Barendt, Freedom of Speech (Oxford: Clarendon, 1985), at 191. We draw on Phillipson (n 2 above) in this section.

120 That is, the argument that since citizens cannot participate meaningfully in a democracy unless they have a reasonable understanding of political issues, open debate on such matters is essential to such a state. See eg A. Meiklejohn, "The First Amendment is an Absolute" (1961) Sup Ct Rev 245 and Political Freedom (1960), at 115-24. Privacy-invading speech may draw something from this argument in areas where it provokes debate on matters of public concern (eg through "outing"). However, such an argument was not raised in any of the cases considered.

121 For the classical argument on truth, see J. S. Mill's On Liberty in M. Cowling (ed), Selected Writings of John Stuart Mill (Cambridge: Cambridge University Press, 1968), at 121; for commentary, see K. Greenwalt, "Free Speech Justifications" (1989) 89 Columbia Law Review 119, at 130-41.

122 That is, the argument that freedom of speech is an essential aspect of the individual's right to moral autonomy: see generally R. Dworkin, "Do we have a right to pornography?" in A Matter of Principle (Cambridge, Mass: Harvard University Press, 1985); T. Scanlon, "A Theory of Freedom of Expression" (1972) 1 Philosophy and Public Affairs 216. 
public eye from making controversial choices about their personal life by forcing them, in effect, to live in a goldfish bowl, it attacks both their autonomy ${ }^{124}$ and their ability to flourish as individuals. ${ }^{125}$

Within the Convention system, it is elementary that Article 10, based as it is upon the essentiality of speech to the "development of everyone"126 and, above all, to the furtherance of a democratic society, ${ }^{127}$ one of the Convention's basic aims, will be much more strongly engaged by some types of speech than others. Specifically, political speech ${ }^{128}$ - which most directly engages the self-government rationale ${ }^{129}-$ is given higher levels of protection at Strasbourg than artistic speech, ${ }^{130}$ with commercial speech

123 That is, the view that the ability to engage in the free expression and reception of ideas and opinions in various media is essential to human flourishing. For general discussion, see C. Emerson, "Towards a General Theory of the First Amendment" (1963) 72 Yale LJ 877, at 879-80; M. Redish, Freedom of Expression (Indianapolis: Michie Co, 1984), at 20-30; K. Greenwalt (n 121 above), at 143-45; J. Raz, "Free Expression and Personal Identification" (1991) 11(3) OJLS 303.

124 As a number of commentators have pointed out, intrusive publications, as well as directly assailing informational autonomy, also indirectly threaten the ability of humans to develop freely in substantive ways: "If people are able to release [private] information with impunity, it might have the effect of illegitimately constraining a person's choices as to his or her private behaviour, interfering in a major way with his or her autonomy" (D. Feldman, "Secrecy, Dignity or Autonomy? Views of Privacy as a Civil Liberty" 47(2) CLP 42, at 54); see also: C. Fried, "Privacy" (1968) 77 Yale LJ 475, at 483; J Rachels, "Why Privacy is Important” (1975) 4 Philosophy and Public Affairs 323; E. F. Paul, F. D. Miller and J. Paul, The Right to Privacy (Cambridge University Press, 2000), at 34-42.

125 As Fried notes, privacy is essential for "respect, love, friendship and trust" "without it they are simply inconceivable" (n 124 above, at 483). Invasion of privacy therefore threatens these essential aspects of human self-expression and development.

126 The ECtHR has often referred to freedom of expression as one of the "essential foundations for the development of everyone": see eg Otto-Preminger v Austria (1994) 19 EHRR 34, at para 49.

127 The ECtHR has repeatedly asserted that freedom of expression "constitutes one of the essential foundations of a democratic society": see eg Observer and Guardian v UK, n 77 above, at para 59; it has spoken of the press's vital role of "public watchdog" in which guise it has a duty "to impart information and ideas on matters of public interest" which the public "has a right to receive" (Castells v Spain (1992) 14 EHRR 445, at para 43).

128 Albeit, the notion of "political" should be broadly defined to go well beyond speech directly relating to governmental activities.

129 The argument for speech from democracy has been described by Barendt as "the most influential theory in the development of twentieth century free speech law," n 119 above, at 68 .

130 See D. J. Harris, M. O'Boyle and C. Warbrick, Law of the European Convention on Human Rights (Butterworths: London, 1995) at 397 and 414. Cf, for example, the decisions in the following cases, which broadly involve artistic speech: Muller v Switzerland (1991) 13 EHRR 212; Gibson v UK (Appl. No. 17634); Handyside v UK, A 24 (1976); Otto-Preminger Institute v Austria (1994) 19 EHRR 34; Gay News v UK (1989) 12 EHRR 123; Wingrove v UK (1997) 24 EHRR 1, esp. at para 58 with the following 'political speech cases': Sunday Times v UK (1979-80) 2 EHRR 245; Jersild v Denmark (1994) 19 EHRR 1; Lingens v Austria (1986) 8 EHRR 407; Thorgeirson v Iceland (1992) 14 EHRR 843; Bladet Tromso v 
coming a poor third. This has been recognised, in other contexts, by the UK courts. ${ }^{131}$ The disclosure of private facts about celebrities by definition concerns the personal, not the public, sphere and will in general scarcely engage the media's right under Article 10 to impart "information on matters of serious public concern" 132 or more general Convention values such as the furtherance of a democratic society.

This point has not, however, been appreciated in a number of English decisions under the HRA. In particular, in some decisions, the courts have chosen to treat the public interest in a story as wholly separate from the issue of the application of Article 10, taking the view that the latter is fully engaged even where the former is wholly absent, ${ }^{133}$ surely a perverse stance, given the European Court's repeated and clear invocations of the vital role of the press in informing the public on matters of serious public concern, ${ }^{134}$ and decisions of the Court which clearly indicate that privacy-invading speech is afforded a very low weight in the Convention system. ${ }^{135}$ A better approach, we argue, would be to treat considerations of public interest not as distinct from the issue of freedom of expression, but as going to the weight of that claim, when it is balanced against privacy. Such an approach has indeed been approved of by dicta in Douglas - cited with approval in $A$ v B plcalthough we argue below that it was not applied in those decisions. In Douglas, Brooke LJ remarked:

"In the absence of any public interest [in the story] the Court is especially bound to pay particular regard to the [Press Complaints Commission Code] and a newspaper which flouts the Code may have its claim to freedom of expression trumped by Article 10(2) considerations of privacy." 136

Such an approach was applied in Douglas II: no public interest was claimed in the publication of the photographs and, given the obvious commercial

Norway (1999) 29 EHRR 125; News Verlags GmbH \& CoKG v Austria (2001) 31 EHRR 8.

131 See recently, Pro-Life Alliance v BBC [2002] 3 WLR 1080 (CA).

132 Bladet Tromso, n 130 above, at para 59.

133 In $A$ v $B$ Plc, Lord Woolf CJ said: "Any interference with the press has to be justified because it inevitably has some effect on the ability of the press to perform its role in society. This is the position irrespective of whether a particular publication is desirable in the public interest" (n 2 above, at 549E, emphasis added). In Theakston, the judge said: "I can see no public interest in the publication of the details of the [sexual] activity" (n 2 above, at para 75); he nevertheless found that: "the freedom of expression of the Sunday People and of the prostitute would be given greater weight than the extra degree of intrusion into the claimant's privacy" (ibid, at para 76).

134 See eg Thorgeir Thorgeirson v Iceland (1992) 14 EHRR 843, at para 50.

135 See $N$ v Portugal, app no. 20683/92 (1995) and Tammer v Estonia (2003) 37 EHRR 43. In the former, a publisher was fined and imprisoned for 15 months, a drastic penalty by any standards, for publishing photographs of a well-known businessman in flagrante with a number of young women. The publisher's application under Art 10 was dismissed as manifestly ill-founded: the penalty was found to be a proportionate response to the legitimate aim of protecting the "rights of others", viz the business man's right to privacy and reputation. The latter decision is discussed below.

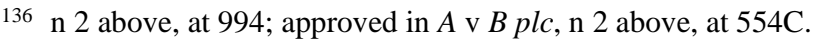


cynicism of Hello!'s actions, the judge found that the clear breaches of the Press Complaints Commission Code through the use of surreptitious photography were such as to tip the balance against freedom of expression. ${ }^{137}$ This, however, is something of an isolated example in the reported cases. ${ }^{138}$

In Douglas, the speech in question - details of a celebrity wedding - was surely a paradigmatic case of low value, non-political speech, satisfying nothing other than a desire for celebrity gossip. It clearly was of substantially less public interest than, say, the speech in question in Tammer $\mathrm{v}$ Estonia. ${ }^{139}$ In that case, the criminal conviction of a journalist in respect of an article he had written was found not to violate Article 10. In the article, the journalist alleged that a former political aide of the Prime Minister had deserted her children and broken up the marriage of the Prime Minister by having an affair with him - clearly somewhat more weighty matters, touching directly on the Prime Minister of the day, than the proposed story and pictures in Hello!. However, the European Court of Human Rights found that because the speech concerned the private life of the political aide, it lacked, for that reason, any substantial public interest and therefore did not constitute a justification for the intrusion into her private life. The court in Douglas, in contrast, appeared to pay no heed to the manifest weakness of the expression claim in Convention terms, while at the same time making a shrewd analysis of the weakness of the privacy interests involved: as Sedley LJ put it, "The first two claimants had sold most of the privacy they now seek to protect to the third claimant for a handsome sum". ${ }^{140}$

The same phenomena appears in both $A \vee B$ Plc and Theakston. Both these decisions concerned low-value, non-political speech, closer to soft pornography ${ }^{141}$ than serious journalism. Moreover, the speech in question, in holding up to public gaze intimate details of the sexual lives of its subjects, was of a type that is arguably actually hostile to core values underlying freedom of expression: such intrusive stories directly attack the value of human development without outside interference from others, ${ }^{142}$ and, through their possible deterrent effect in threatening the humiliating exposure of sexual irregularities, indirectly threaten substantive autonomy. ${ }^{143}$ Again, however, the court, while showing no awareness of these clear weaknesses in the speech claim, went to some lengths to point out the relative poverty - as the judges saw it - of the privacy case. Indeed the court in $A \vee B$ laid down guidance to the effect that it may not even be necessary to determine the existence of weaker privacy claims, so likely were they to be outweighed by the claims of freedom of expression:

137 n 2 above, 204-05.

138 Expression rights did not succeed in the Venables and Thompson case (n 2 above): however, it is important to point out that in that case the boys' right to life was engaged as a countervailing consideration.

139 See $\mathrm{n} 135$ above.

$140 \mathrm{n} 2$ above, at 1006, per Sedley LJ.

141 Sedley LJ has described it as "mildly pornographic" material: Cream Holdings, $\mathrm{n}$ 97 above, at 88 .

142 See $\mathrm{n} 123$ and 126 above. For the facts of these cases, see $\mathrm{n} 2$ above.

143 For the argument that freedom of expression can best be justified by an argument based on moral autonomy, see the works cited in $n 122$ above. 
". . . usually the answer to the question whether there exists a private interest worthy of protection will be obvious. In those cases in which the answer is not obvious, an answer will often be unnecessary. This is because the weaker the claim for privacy, the more likely that the claim for privacy will be outweighed by the claim based on freedom of expression."144

This reasoning is revealing: it shows no recognition of the proposition that whether the privacy interest is likely to be outweighed by the speech interest depends upon the nature of the speech in question. It thus neatly encapsulates the unbalanced approach to the two Convention rights described above.

The courts in both cases then went on to apply this approach, examining at some length the weaknesses of the privacy interest, while disregarding the nature of the speech. Given the transitory nature of the intimate relationships in question and the fact that the other parties to them did not wish to keep them private any longer, the Court in $A$ v B Plc concluded: "In our view, to grant an injunction would be an unjustified interference with the freedom of the press." 145 In Theakston, the conclusion, reached specifically on the right of the newspaper to convey intimate and prurient detail of the precise sexual acts that took place between Theakston and the prostitutes was even clearer:

"I do not consider that the confidentiality or privacy case in relation to the details of the sexual activity is nearly strong enough to warrant the degree of restriction involved." ${ }^{146}$

This was said despite the fact that the judge openly conceded that conveying such details to the public had no public interest value. ${ }^{147}$ We would argue that the opposite was the case in both instances: the speech in question conveying explicit details of the sexual activity of a celebrity - was surely of the lowest value in Convention terms; conversely, the invasion of privacy, entailing as it did a gross intrusion into one of the most intimate aspects of private life - sexuality - was surely of a very grave degree. Such cases therefore can quite straightforwardly be resolved in favour of the privacy interest at the level of principle. But as long as the courts continue to perceive Article 10 as engaging a one-size-fits-all weight, such a resolution will not present itself.

\section{The "Public Interest" In English Privacy Cases: A Development Too Far?}

The courts' particular finding on what the public interest specifically demanded are equally of interest. In $A \vee B$ plc, Lord Woolf CJ laid down as general guidance the following:

"Even trivial facts relating to a public figure can be of great interest to readers and other observers of the media. In many of these situations it would be overstating the position to say

\footnotetext{
$144 \mathrm{n} 2$ above, at 550C.

$145 \mathrm{Ibid}$, at 561 .

$146 \mathrm{n} 2$ above, at para 76 (emphasis added).

147 "I can see no public interest in the publication of the details of the [sexual] activity" (n 2 above, at 75).
} 
that there is a public interest in the information being published. It would be more accurate to say that the public have an understandable and so a legitimate interest in being told the information. If this is the situation then it can be appropriately taken into account by a court when deciding on which side of the line a case falls." ${ }^{148}$

One of the authors has criticised this reasoning extensively elsewhere. ${ }^{149}$ Only two points need be made here: first, it collapses the distinction, carefully maintained in successive previous judgments of the Court of Appeal, between "the public interest" as a legal term of art on the one hand, and what is interesting to the public on the other. ${ }^{150}$ Second, it takes no heed of the fact that Strasbourg, in a number of cases, has treated publications that invade private life as lacking, for that reason, a public interest, such that even very draconian penalties in relation to them have readily been found to be justified as a proportionate means of protecting private life under Article 8 . As a leading work on privacy puts it: ${ }^{151}$

"Where the content [of the relevant publications] amounts to a gross invasion of privacy the Commission has had no difficulty in considering severe penalties (including imprisonment) for the publisher concerned to be a proportionate interference with his right to freedom of expression. ${ }^{152}$ Such publications are considered to have little or no informational value worth protecting."

The other strand of argument that the courts used to support the right to publish in both $A$ v $B$ and Theakston was the proposition that the figures in question, while not politicians, were role models of a sort and that it is important for the public not to be misled about such people. This notion, while it appears in the Press Complaints Commission Code to which the courts must have regard, ${ }^{153}$ is one which surely must be approached with caution in principle, and was in any event pressed into action in these cases in a way that was thoroughly muddled. In $A \vee B$, the court laid down the general guideline that:

"[A] public figure may hold a position where higher standards of conduct can be rightly expected by the public. [He] may be a role model whose conduct could well be emulated by others. He may set the fashion." 154

Applying this to the facts before it, Lord Woolf CJ found:

148 n 2 above, at 552.

149 Phillipson, n 114 above.

150 See eg Lion Laboratories [1985] QB 526, at 537; Francome [1984] 1 WLR 892, at 898; LRT v Major of London [2003] EMLR 40.

151 M. Tugendhat QC and I. Christie, The Law of Privacy and the Media (Oxford University Press, 2002), at 420-21.

152 Here the authors cite $N$ v Portugal, app no. 20683/92 (1995) and Tammer v Estonia, (2003) 37 EHRR 43.

153 Under s 12 HRA.

154 n 2 above, at para 11(xiii). 
“. . . it is not self-evident that how a well-known premiership football player [Gary Flitcroft] chooses to spend his time off the football field does not have a modicum of public interest. Footballers are role models for young people and undesirable behaviour on their part can set an unfortunate example." 155

It is interesting to compare this passage with the reasoning of the Supreme Court in NIB $v$ RTE in addressing the issue of the public interest defence; it vividly illustrates how far the English courts have taken the defence of public interest from the notion of protecting the public from serious harm. Ironically, perhaps, in this case an old-fashioned "no-confidence-in-iniquity" defence could have been used, since adultery is certainly "immoral" in the traditional sense. But instead, as seen above, the judge focused upon the supposed benefit to the public in knowing the information concerned. In particular, the Court of Appeal judgment in $A \mathrm{v} B$ suggests that the interests of young men, who may be influenced by footballers, in being informed of the true state of their sexual behaviour, outweighs the right not to have intimate details of one's sexual life publicised to the world at large. The contrast with NIB v RTE, in which the Supreme Court agonised over how far the revelation of widespread, criminal tax evasion was in the public interest, could not be stronger. The Court of Appeal moreover seems somewhat confused as to what benefit the young men supposedly influenced by the behaviour of Gary Flitcroft would receive from having immoral behaviour on his part publicised. The reference to the fact that such behaviour may "set an unfortunate example" indeed suggests that they may be harmed by finding out such matters. Yet this was somehow seen as a sufficiently weighty public interest to outweigh what, in Strasbourg terms, was undoubtedly a serious invasion of private life.

\section{CONCLUSIONS}

In conclusion, then, whilst the Irish courts are only very slowly and tentatively expanding the boundaries of the public interest defence beyond the revelation of serious wrong-doing, the English courts, in one case at least, have stretched it to include the public's desire to receive gossip that may affect their opinion of the sexual continence of premiership footballers. By so doing, English judges are allowing Article 10 to cast a protective mantle around speech that holds up the personal life of celebrities for public entertainment, and in so doing assaults human dignity, personal autonomy, and what Strasbourg ${ }^{156}$ has referred to as the value in the "development, without outside interference, of the personality of each individual in his relations with other human beings." ${ }^{157}$ The latter value has, indeed, been frequently recognised by the Strasbourg Court as one underlying the right of free expression; ${ }^{158}$ it is ironic therefore to see Article 10, intended in part to enhance the self-development of the individual, being pressed into service to justify speech that assaults and impedes that freedom.

155 Ibid, at para 45.

156 In Botta v Italy (1998) 26 EHRR 241.

157 See n 124 above.

158 The ECtHR has repeatedly asserted that freedom of expression is one of the "essential foundations for the development of everyone" (Otto Preminger Institute v Austria (1994) EHRR 34, at para 49). 
This paper has argued that the public interest test in the Irish law of confidence needs to be developed substantially beyond its current state in order fully to reflect the demands of Article 10, but that the English line of case law post-HRA on the public interest defence in personal information cases serves as a clear warning that such development needs to be firmly grounded in the values underlying freedom of expression itself. Thus the class of tabloid speech about the sexual lives of celebrities, which has no part to play in informing public debate on matters of public concern, and which tends to run counter to the values of human autonomy and human flourishing, should emphatically not be seen as serving any public interest, when that notion is configured not merely as judicial intuition as to what is desirable for society generally, but as one structured by the principles underpinning the right to free expression itself. If such a course is followed, Irish courts could not only markedly enhance Irish law's recognition of the importance of freedom of expression in a democratic society, but also avoid the abuse of that concept in the service of gutter journalism that degrades both individuals and our public culture. The Irish courts should enhance their role as guardians of fundamental rights and the public interest properly so-called, not become the guardians of the gutter press.

\section{POSTCRIPT}

As this article was going to press, the House of Lords decision in Campbell $\mathrm{v}$ $M G N$ [2004] UKHL 22 was handed down. In a lengthy judgment of over 60 pages, their Lordships decided by three to two that the publication of the details of Naomi Campbell's treatment at Narcotics Anonymous and of photographs of her leaving a particular meeting with other patients amounted to a breach of confidence that could not be justified in the public interest and/or under Article 10 ECHR, thus overturning the Court of Appeal decision. This judgment, one of the most important in terms of media freedom since the HRA came into force, is also of tremendous significance for the area of law with which this article is concerned. In particular, their Lordships unanimously confirmed that the correct approach to balancing speech and privacy interests is that outlined by the authors above and used in $\operatorname{Re} S$ (see note 104 above) - that is, the dual use of proportionality: see in particular the speech of Lord Hoffman at paragraph 55, of Lord Hope at paragraph 113 and Lady Hale at paragraph 140-141. Their Lordships also set the most authoritative possible seal on the use of a radically modified form of breach of confidence to protect privacy: it not only clearly discards any need for a prior relationship between the parties, but also sets breach of confidence in a new conceptual framework. As Lord Nicholls summed it up: "The essence of the tort is better encapsulated now as misuse of private information" (at paragraph 41). Finally, the speech of Lady Hale in particular showed a clear recognition of the need, expressed above in this article, to approach the public interest test by reference to the values underpinning Article $10 \mathrm{ECHR}$ and in particular the notion that different categories of speech have different levels of importance under that Article (see paragraph 148) with reportage of celebrity gossip coming low down in the scale. As her Ladyship put it, "The political and social life of the community, and the intellectual, artistic or personal development of 
individuals, are not obviously assisted by pouring over the intimate details of a fashion model's private life." (at paragraph 149; see also the speech of Lord Hope, at paragraph 117). Thus the judgment also appears likely to inhibit future judicial acceptance of the kind of flimsy public interest arguments that this article has criticized. 